\title{
Paratracheal Lymph Node
}

National Cancer Institute

\section{Source}

National Cancer Institute. Paratracheal Lymph Node. NCI Thesaurus. Code C103426.

A lymph node located adjacent to the trachea within the mediastinum. $(\mathrm{NCl})$ 